\title{
Paying for Transit in an Era of Federal Policy Change
}

\author{
Jeffrey Brown, Florida State University
}

\begin{abstract}
Public transit agencies rely on a combination of local, state, and federal subsidies to provide their services. However, federal policy changes have introduced uncertainty into the public subsidy picture. In 1998, Congress passed TEA-21, which eliminated federal operating assistance to agencies in U.S. urbanized areas with populations of 200,000 or more persons. This policy change came at the end of a more than decadelong decline in the share of federal operating support for agencies in larger urban areas. This article examines how agencies in different parts of the country and in different-sized urban areas have responded to federal policy changes by posing a simple question: Where have agencies turned to make up the operating fund shortfall? The investigation reveals that agencies in different parts of the country have followed different financial paths.
\end{abstract}

\section{Introduction}

Public transit is a subsidized service. Passenger fares cover, on average, 37 percent of the typical transit agency's annual operating expenses (Federal Transit Administration 2002). To make up the shortfall, agencies rely on a combination of local, state, and federal subsidies. However, recent policy changes at the federal level have significantly altered the public subsidy landscape.

In 1998, Congress passed the Transportation Equity Act for the 21st Century (TEA21). This law provided more than $\$ 200$ billion in federal highway and transit funds 
over six years. However, it also eliminated federal operating assistance to transit agencies in U.S. urbanized areas with populations of 200,000 or more persons (Federal Register 1998). Operating expenses, which include such expense categories as employee wages and benefits, vehicle maintenance expenses, and vehicle fuel expenses, account for nearly two-thirds of a typical transit agency's annual expenses, so the change in federal policy has significant financial implications for affected agencies (Federal Transit Administration 2002).

The TEA-21 policy change comes at the end of a decade-long retreat from largescale federal operating support (NTD, various years). For a variety of financial, institutional, and philosophical reasons, the federal government was initially hesitant to take on the financial commitment to provide operating assistance, and administrations of both parties had long sought to reduce or eliminate this commitment (Jones 1985; Brown 2003). In TEA-21, they finally achieved their long-sought goal.

This article explores how transit agencies have responded in this changed subsidy environment. It pays particular attention to how these responses differ among agencies in different parts of the country and in different sized urban areas. The essential question of the investigation is: Where have transit agencies turned to make up the shortfall of federal operating support? Agencies conceivably could turn to a variety of state and/or local finance sources ranging from general revenues to dedicated property taxes or sales taxes. The examination reveals that agencies in different parts of the country have turned in very different directions.

\section{Federal Aid to Public Transit}

The federal government began providing financial assistance, in the form of small capital grants, to transit agencies in the early 1960s (Hilton 1974; Jones 1985). But beginning with passage of the National Mass Transportation Assistance Act of 1974, this modest capital grant program grew into a much larger program that provided both capital and operating assistance. The decision to provide operating assistance was not without controversy, and, in the two decades since operating assistance was first made available, program critics and administrations of both parties have tried to reduce federal financial involvement in this area (Brown 2003; Winston and Shirley 1998). ${ }^{1}$

Beginning in the mid-1990s, the Clinton administration, in partnership with a Republican-controlled Congress, enacted large cuts in operating assistance to transit agencies in large urbanized areas through annual appropriations legisla- 
tion (U.S. Department of Transportation Annual Appropriations legislation, FY 1994-2000). ${ }^{2}$ When it came time to reauthorize the federal transit program, one of the issues on the agenda was the possible elimination of all federal operating assistance (Congressional Record 1997). Over the course of the 1997 and early 1998 debates, the focus shifted from the elimination of all federal operating assistance to the elimination of assistance to so-called "big city" agencies. These were agencies that served urbanized areas with more than 200,000 persons. During committee testimony and floor debate in both the House and Senate, proponents of the policy change claimed that agencies in these larger urban environments had access to many other potential sources of operating subsidy, while those agencies located in rural and "small city" environments were so dependent on federal operating support that service might disappear if they lost their federal subsidy (Congressional Record 1998).

When the TEA-21 was passed in 1998, it eliminated federal operating assistance to agencies located in urbanized areas with more than 200,000 persons. ${ }^{3}$ Rural and small city agencies continued to be eligible for assistance. A handful of affected "big city" agencies negotiated a short transitional period wherein they would receive some operating support, and similar negotiations are taking place in the background of the current (2005) surface transportation reauthorization (Federal Register 1998; APTA 2004). But for most "big city" agencies, the federal operating subsidy valve has begun to close.

\section{Research Questions, Data, and Methodology}

The elimination of federal operating assistance to agencies in urbanized areas with more than 200,000 persons is a significant policy change. When coupled with maintenance expense categories, operating expenses account for nearly twothirds of the typical U.S. transit agency's annual expenses (Federal Transit Administration 2002). Because agencies are heavily dependent on subsidies from federal, state, and local government, the elimination of operating support from one level of government could cause significant stress on some transit agencies, particularly if this source of support accounted for a large share of agency budgets.

This article seeks to determine how recent federal policy changes have affected transit agencies around the country. The investigation considers two research questions: 
1. How has the federal share of operating expenses changed, and where have agencies gone to make up any shortfall?

2. How do these changes differ among agencies in different sized urbanized areas and/or different regions of the country?

To answer these questions, data collected by the Federal Transit Administration for the annual National Transit Database (NTD) were employed. Data have been extracted from the NTD using an extraction program called FTIS that was developed by the Florida Department of Transportation (FDOT). This research focuses on the period from 1984 to $2001 .{ }^{4}$ The investigation includes a handful of key NTD financial variables: passenger fare revenues, local general revenues, state general revenues, local-dedicated funding sources (gas tax, sales tax, property tax, income tax), state-dedicated funding sources (gas tax, sales tax, property tax, income tax), total local funds, total state funds, total federal funds, and total expenditures. Data for these funding sources were obtained for capital expenditures, operating expenditures, and total expenditures. However, the focus of this investigation is on operating expenditures, and all data cited here are for operating expenditures alone.

Transit agencies were grouped into categories by census region (Midwest, Northeast, South, and West) and by urbanized area population size (under 200,000; 200,000 to 250,$000 ; 250,000$ to 500,$000 ; 500,000$ to 1 million; over 1 million). ${ }^{5}$ The regions also were broken down into the population size categories. Agencies in the New York urbanized area were placed in a separate category due to New York's disproportionate share of national transit patronage. The wide array of agency groupings permitted an investigation of regional variation in reliance on different finance instruments and allowed for a contrast between agencies affected (over 200,000 persons in urbanized area) and not affected (under 200,000 persons in urbanized area) by the most recent federal policy change. National averages are included for reference.

\section{Operating Expenditures}

In 2001, U.S. transit agencies spent $\$ 12$ billion for operating expenditures (NTD 2002). This represented a 22.4 percent increase since the passage of TEA-21 (1998) and a 68.4 percent increase since the passage of ISTEA (1991) (see Table 1). Operating expenditures grew fastest among agencies located in smaller (under 200,000 persons) and mid-sized (250,000 to 500,000 persons) urbanized areas throughout the nation, and slowest in the Northeast where transit systems and transit usage 


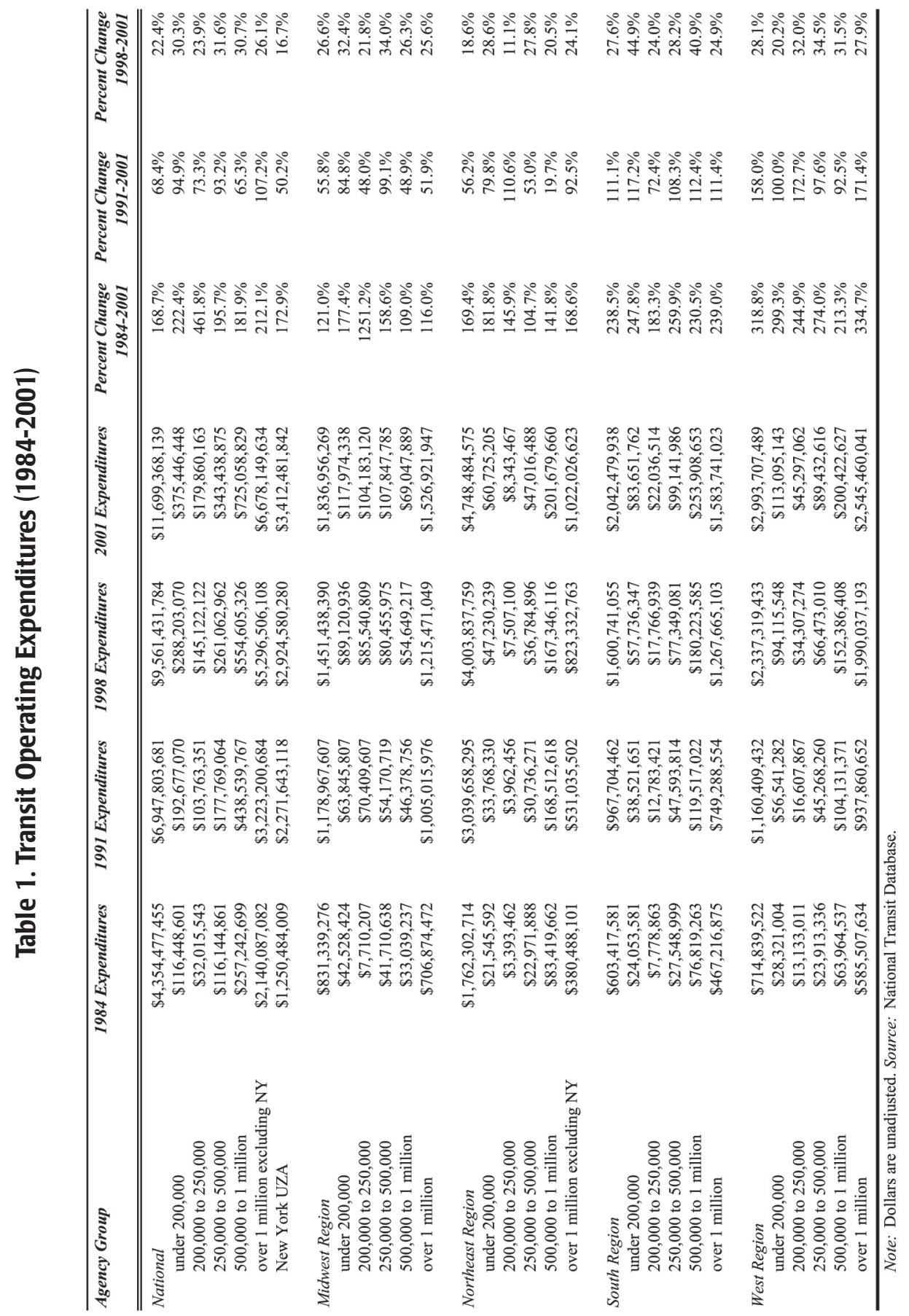


are more established. The annual operating expenditure increases of the late 1980s and early 1990s were consistently significant at a .05 significance level.

The increase in operating expenditures reflects a growth in transit service provided throughout the nation. Transit service rose from 2.3 billion vehicle miles of service in 1984 to 3.7 billion vehicle miles in 2001, an increase of 62 percent (NTD 2002). While the U.S. transit industry has had its well-chronicled ups and downs with patronage figures, particularly during the early 1990s, the ridership trend also has been upward over the long term (Pucher 2002). Between 1984 and 2001, transit ridership rose from 35 billion to around 47 billion passenger miles, an increase of 31 percent.

Transit agencies are providing more transit service, operating more vehicles over more route miles. Transit customers are consuming more service. Both trends are evident among agencies in both large and small urbanized areas throughout the country. So, how are transit agencies paying to operate this service?

\section{Federal Operating Subsidy}

The premise of this investigation is that, due to federal policy changes, transit agencies should be less reliant on federal operating subsidy and more reliant on either fare revenue or subsidy from some other revenue source. This issue is investigated in two ways: first, by looking at federal operating subsidies expressed in dollar terms, and second, by considering federal operating subsidies as a percent of all operating expenses.

When raw dollars are involved, a very mixed picture emerges of the decline in aid to some regions and among certain urbanized area classes and continued increases in others (see Table 2). On a regional basis, federal operating subsidies (in dollar terms) are increasing fastest in the Midwest and West and slowest in the Northeast (NTD, various years). On a population basis, the New York urbanized area and the larger population groups, particularly in the Northeast, have fared the worst; smaller urbanized areas (under 200,000 persons) have experienced some of the largest increases. ${ }^{6}$ Surprisingly, among all groups, only the New York urbanized area has experienced declines in the dollars of federal operating subsidy since 1998 (-17.2 percent). The other agency groups have experienced increases. This was unexpected because of the 1998 policy change. However, it might be explained by some combination of the following: (1) loosening of eligible expense rules that enables some expenditures previously classified as operating to be funded from capital sources, (2) negotiation between an agency and federal officials for a tran- 
sitional period to slowly reduce dependence on federal subsidy, or (3) a lag effect in the data. There is strong evidence for the first and second explanations. Many expenses that at one time were categorized as operating are now eligible as capital or maintenance, and a small number of large city transit agencies have indeed negotiated transitional periods in which they still are eligible for some federal operating assistance (Federal Transit Administration 2005; Federal Register 1998).

The second approach to assessing the level of agency reliance on federal operating subsidy is to examine the proportion of agency operating expenses accounted for by federal operating assistance. Perhaps this approach will reveal the expected federal retrenchment. Indeed, there is strong evidence of federal retrenchment when we look over both the long (1984 to 2001) and medium (1991 to 2001) term; however, the short term (1998 to 2001) presents a more mixed picture (see Table 3).

From 1984 to 2001, all but one of the agency groups experienced double-digit declines in the proportion of operating expenses covered by federal subsidy. Nationally, the average agency has 9.6 percent of its operating expenses covered by federal subsidy, with the smaller population urbanized areas generally well above this average and the larger urbanized areas generally below the average. In general, agencies in the Northeast are least dependent on federal subsidy than those located elsewhere. The Northeast region experienced the largest declines in federal subsidy share over the period examined, and the West and South regions experienced the smallest declines.

Despite the mixed results of the post-TEA-21 period, the longer-term trends are consistent with the initial hypothesis. Federal dollars have not declined as significantly as expected, but the federal share of operating expenses certainly has. Agencies have not responded to this shift by reducing service; service is growing and so is patronage. So where are agencies turning to pay for this expanded service?

\section{Passenger Fare Revenue}

One obvious source of new revenue is the farebox. However, increased fares can also reduce ridership. The transit industry's rule of thumb, the Simpson-Curtin formula, states that every 1 percent increase in fare reduces ridership by one-third of 1 percent-a fare elasticity of -.33 (McCollom et al. 2004). However, riders' sensitivity to fare increases varies by rider demographics, time of day, nature of the transit service, and size of the city (Litman 2004a). Based on an extensive literature review, Litman (2004a) recommends the use of short-term overall fare elasticities 


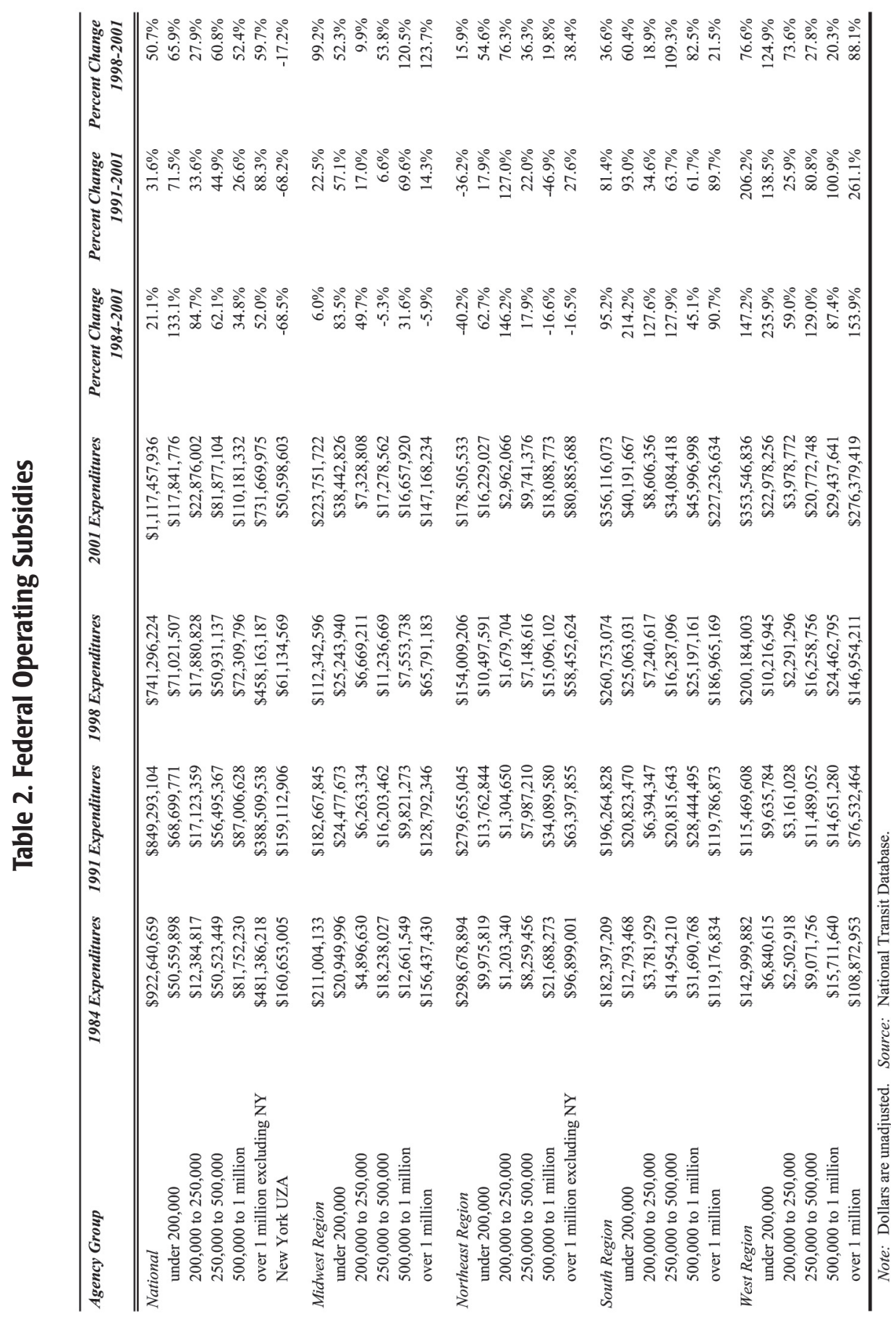




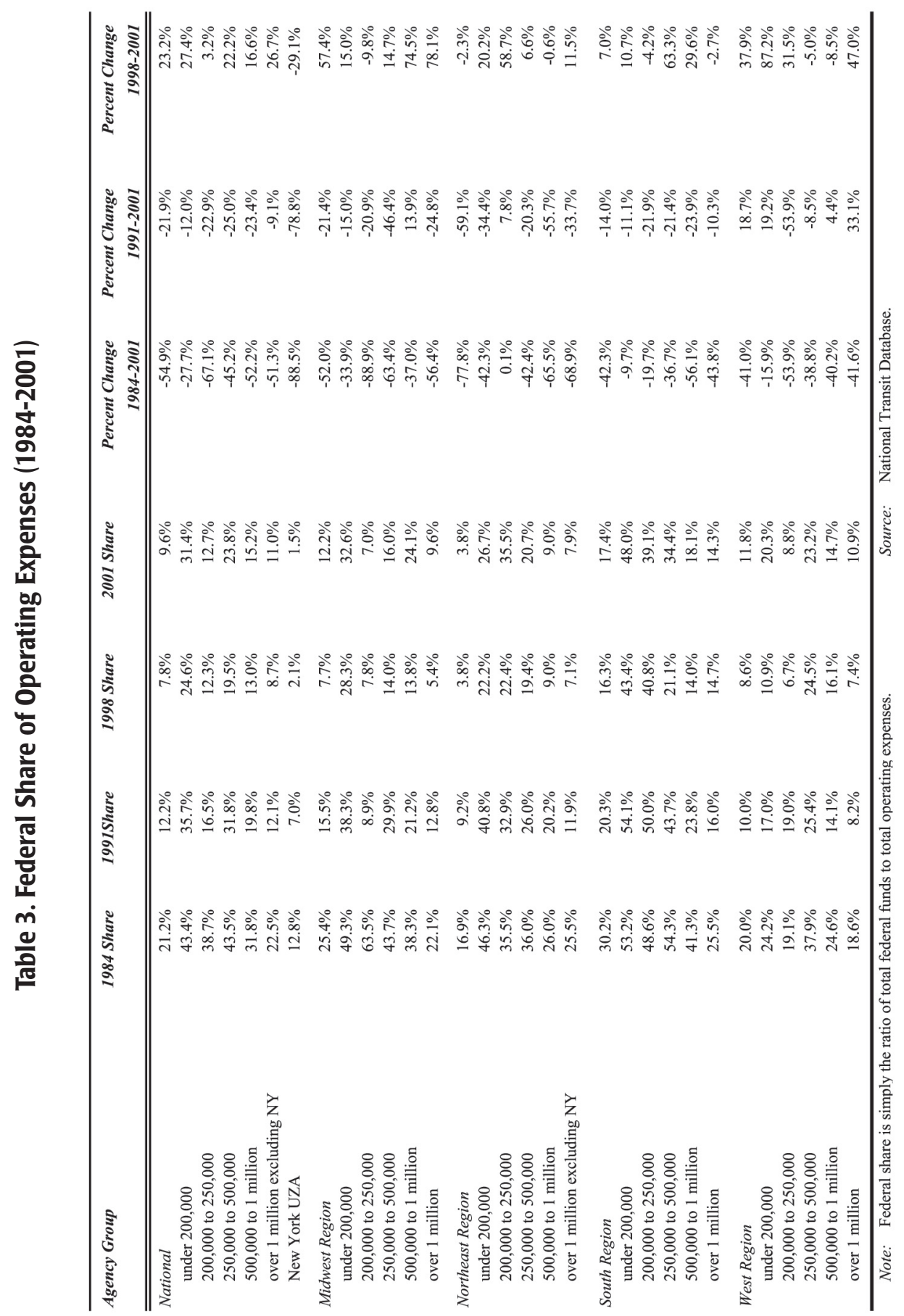


in the range of -.2 to -.5 and long-term overall elasticities in the range of -.6 to $-.9 .^{8}$ Even at the high end of elasticity values, passenger fare increases will lead to net revenue gains for a transit agency. So, have agencies instituted higher passenger fares?

Passenger fare revenues have increased over the period examined, but they have not kept pace with the increase in operating expenditures in recent years (NTD, various years). ${ }^{9}$ Nationally, passenger fare revenues have increased 49 percent since 1991 and 13 percent since 1998. But operating expenditures increased 68 percent since 1991 and 22 percent since 1998 (see Table 1). Thus, farebox recovery rates have fallen.

Nationally, passenger fares cover 37 percent of operating costs, but this figure varies a great deal among different classes of agencies (see Table 4). Among the regions, farebox recovery ratios are highest in the Northeast, and lowest in the West. Among population groups, ratios tend to be lowest among agencies in midsized urbanized areas.

Farebox recovery ratios have fallen among most groups of agencies since 1998, although the picture is more mixed for the 1991 to 2001 period. From 1991 to 2001, farebox recovery ratios improved among most agencies in urbanized areas with fewer than 200,000 persons, among most agencies in the West census region, and in Northeastern urbanized areas with more than 500,000 persons. These agencies have responded to the retrenchment of federal aid, at least in part, by increasing passenger fares. For agencies in most other groups, particularly in the Midwest region, passenger fare revenues are declining as a proportion of operating expenses. These agencies have to look to other revenue sources to make up their financial shortfall.

\section{Subsidy Options}

In addition to increasing fare revenues, agencies seeking additional operating revenues have a number of revenue-generating strategies and public subsidy options available to them. Agencies can try to increase their directly-generated funds, such as money paid for advertising on vehicles or for special contracted services. Many agencies are doing so, although the dollars involved in these arrangements are a miniscule share of most agency budgets (Price Waterhouse et al. 1998). By and large, agencies are turning to state or local governments for the money they need. First, we will consider state finance mechanisms, and then we will consider their local counterparts. 


\section{State Finance Mechanisms}

State governments provide financial assistance to public transit agencies through a variety of means. All states provide some general revenue support to public transit. In most states, legislatures and/or the voters have dedicated a proportion of motor fuel tax revenue to support public transit. Many states have dedicated a proportion of state sales tax revenues to support transit. A few states dedicate property tax or income tax revenues to fund transit. As the analysis below indicates, however, reliance on particular state finance instruments often is confined to a very narrow group of agencies.

Nationally, state government expenditures on public transit operations nearly tripled between 1984 and 2001, from $\$ 1.7$ to more than $\$ 5.1$ billion (NTD, various years). State operating assistance increased to agencies throughout the country located in all size urban areas. But this increase in dollar expenditures was expected, given the increase in transit operating expenditures in general. The question is whether this increase kept pace or exceeded the overall rate of operating expenditure increase. The ratio of state aid to total operating expenditures is one measure we can use to examine this question. The results of the analysis are presented in Table 5.

In 2001, state aid was 43.8 percent of the amount expended nationally for transit operations. This represents a 10 percent increase from 1984. The percent was highest among agencies located in the Northeast and lowest among those located in the West. On a regional basis, agencies located in the Midwest and South are becoming more dependent on state aid, while those in the West and Northeast are experiencing a modest increase in their reliance on state-level finance instruments. State aid could come from a variety of sources, including both general revenues and dedicated sources like motor fuel, sales, property, or income taxes. Each of these instruments is considered in the paragraphs below.

State General Revenue. One major source of state financial assistance is general revenue support. In 2001, state general revenue assistance for transit operating expenses exceeded $\$ 1.7$ billion and represented one-third of all state financial support (NTD 2002). State general revenue assistance was about 14 percent of the value of transit operating expenditures. This represents a nearly 50 percent decline since 1984 (see Table 6). State general revenue support has been most important in the Northeast and among agencies in the smallest sized urbanized areas in the Midwest and South and least important in the West. 


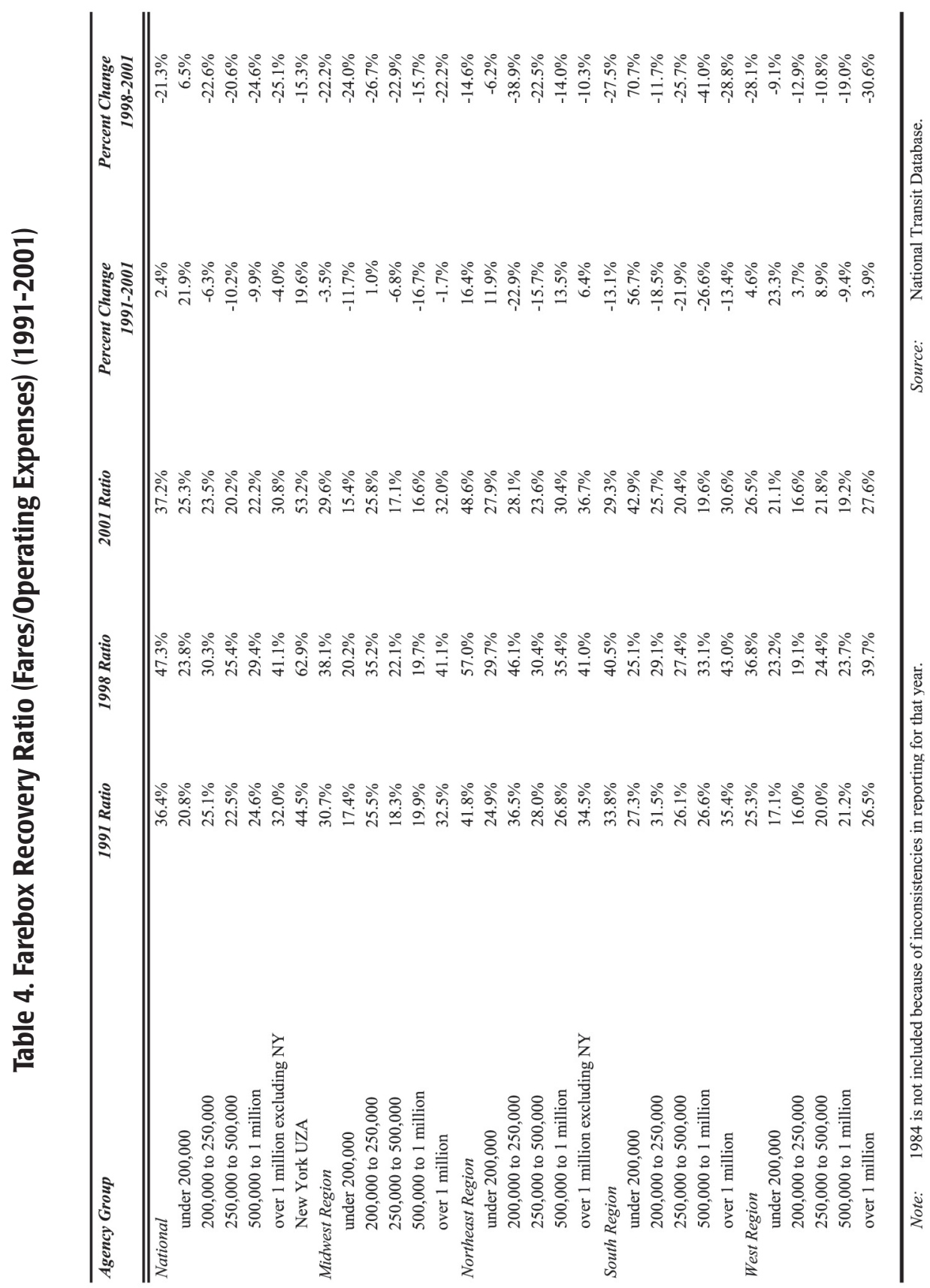




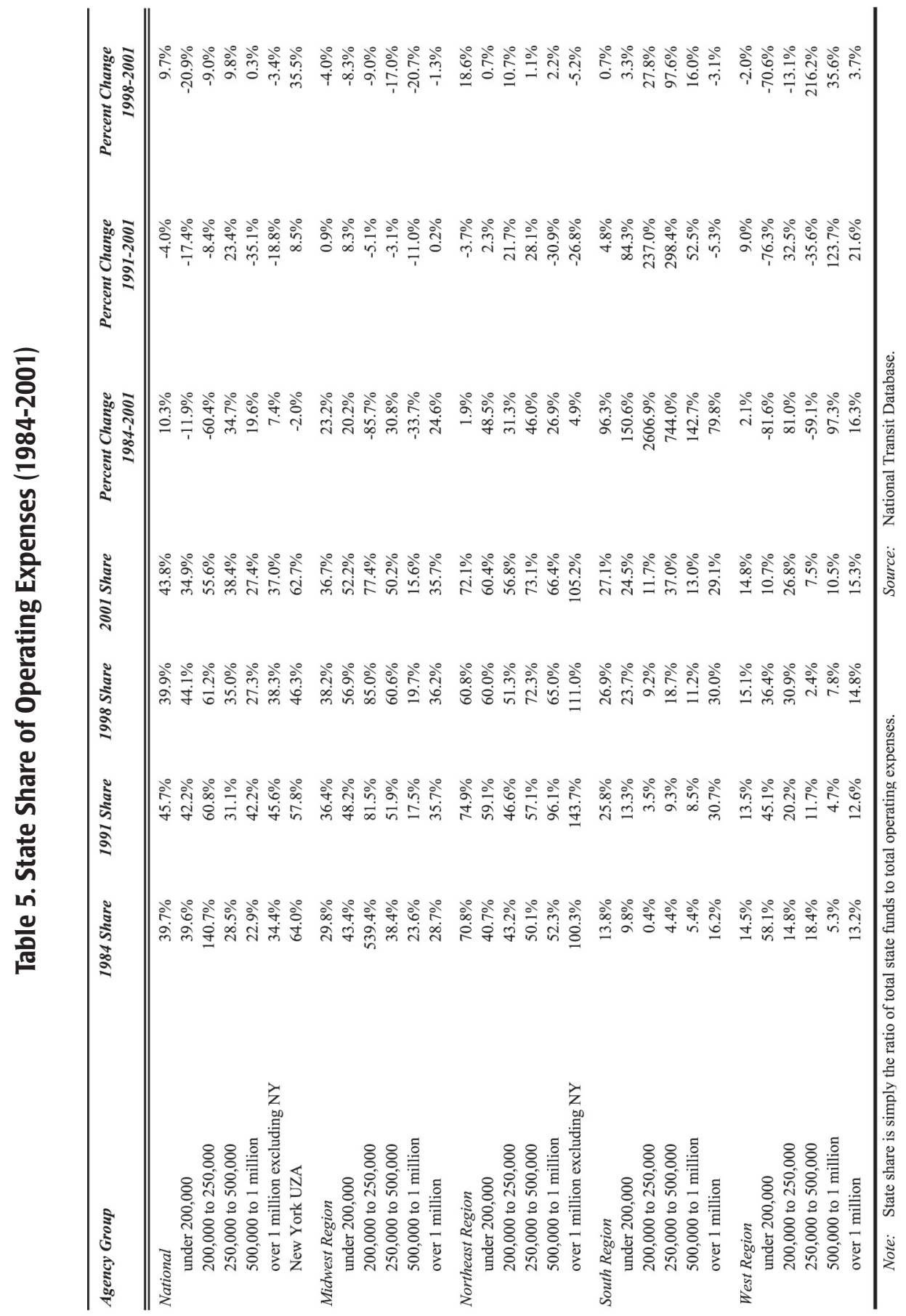




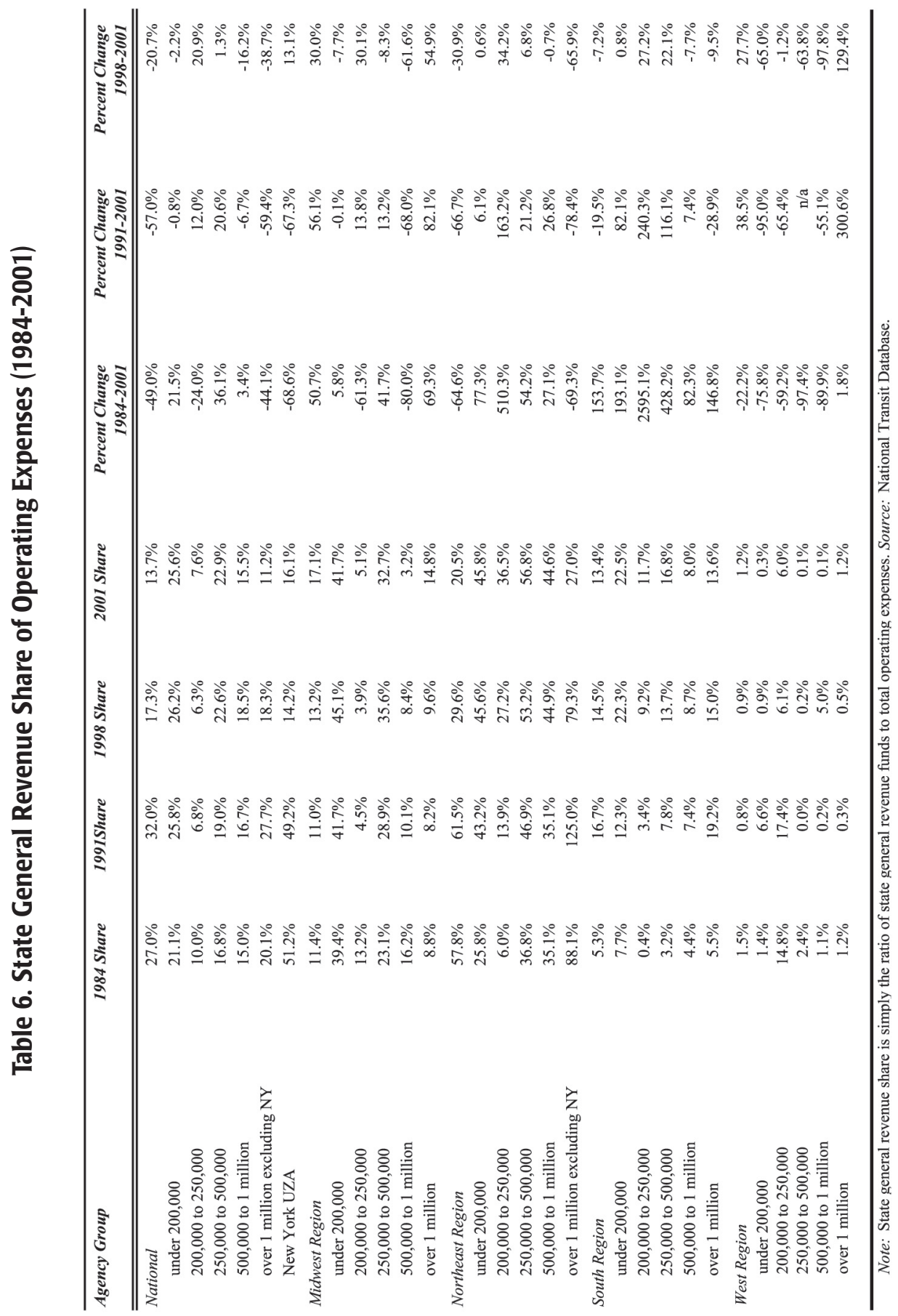


Table 6 shows that agencies in most urbanized areas with over 500,000 persons are becoming less reliant on state general fund support, while agencies in urbanized areas with between 200,000 and 250,000 persons are becoming more reliant on this measure. Elsewhere, the trends are mixed; although, in many cases where the largest percentage increases are evident, the actual dollars and percent shares are quite small (as, for example, among agencies in West region urbanized areas with more than 1 million persons).

To the extent that states, or even localities, rely on income taxes for the bulk of their general revenues, this method of transit finance can be progressive with respect to income, but it may be viewed as inequitable because it bears no direct relation to one's use of the service provided with the funds, the user-pays perspective (Litman 2004b; Pechman 1985). The use of such funds to support transit has, however, been justified - and largely accepted - on the grounds that transit is a necessary social service (Litman 2004b). However, increased reliance on general revenue is not ideal because transit must compete with other public services for these often-scarce dollars. An alternative approach is to pursue a dedicated revenue stream, and there are several instruments available at the state level, ranging from dedicated taxes on gasoline to dedicated taxes on income.

State-Dedicated Gas Tax. Motor fuels taxes have been an important source of dedicated transportation funding since before the creation of the federal Highway Trust Fund in 1956 (Brown 2003). Like other taxes based on consumption, state or local gasoline taxes are regressive with respect to income (Pechman 1985; Johnson and Tenny 2002). Such taxes may also be viewed as inequitable by some because, although they are related to use of the highway system, they bear no relation to use of public transit.

Dedicated state motor fuels taxes have played an important role in public transit finance, including for operating support. Today, state-dedicated motor fuel tax revenues are not a very large component of transit operating support. Nationally, they are around 3.4 percent of total operating expenses. They are most important for agencies in Midwest and Northeast urbanized areas with between 500,000 and 1 million persons and among agencies in the New York urbanized area (see Table 7). These are also the only groups of agencies for which they have increased in importance over the most recent period (1998-2001), although they have increased elsewhere over the long term (1984-2001). State-dedicated gas taxes are not very important sources for transit operating support in most other parts of the country. 
State-Dedicated Sales Tax. In recent years, many governments have turned to dedicated sales taxes as a mechanism to finance certain public services, including transit (Goldman and Wachs 2003). This has been particularly true at the local level, but there is also a long history of state-level sales tax support for transit, as in the case of California's Transportation Development Act (Taylor 1991). In 2001 , more than $\$ 1$ billion in state-dedicated sales tax revenue was expended on transit operations, more than two-thirds of it by transit agencies in the Northeast region (NTD 2002). This revenue source is particularly significant for agencies in Northeast region urbanized areas with more than 1 million persons ( $\$ 747$ million in 2001), including New York, and in West region urbanized areas with more than 1 million persons ( $\$ 268$ million in 2001), including the major urban centers in California. It is relatively unimportant elsewhere (in the single digits as a percent of total operating expense), and is in decline (see Table 8). Dedicated (state or local) sales taxes are at least as regressive as gasoline taxes and, although increasingly popular in certain regions, their adoption has been lamented by many scholars concerned that they bear no relation to use of the transportation system (Pechman 1985; Goldman and Wachs 2003).

State Property Tax and State-Dedicated Income Tax. At a national level, statededicated property tax and state-dedicated income tax revenues are relatively modest components of the typical agency's operating budget, and likely to remain so. The property tax and income tax are among the least regressive of the various finance instruments discussed here with respect to income, although they are divorced from actual use of transit, and thus may run afoul of equity arguments (Johnson and Tenny 2002; Pechman 1985). State-dedicated property tax revenues are an important revenue source among agencies in the New York urbanized area and, until recently, among agencies in Western urbanized areas with more than 1 million persons as well. In 2001, \$15 million was raised from this revenue source, nearly all of it expended by New York urbanized area agencies (NTD 2002). In the past, big-city Western agencies expended about two-thirds of the national total raised from state property taxes for operating support, and almost all the remainder was expended in New York, but there has been a steep decline in its use by these agencies. The trend in usage of this instrument has been relatively flat throughout the country.

State-dedicated income taxes also fall into the category of a geographicallyfocused finance instrument. In 2001, more than $\$ 250$ million of the \$260 million raised from this source for transit operating expenses was expended by agencies 


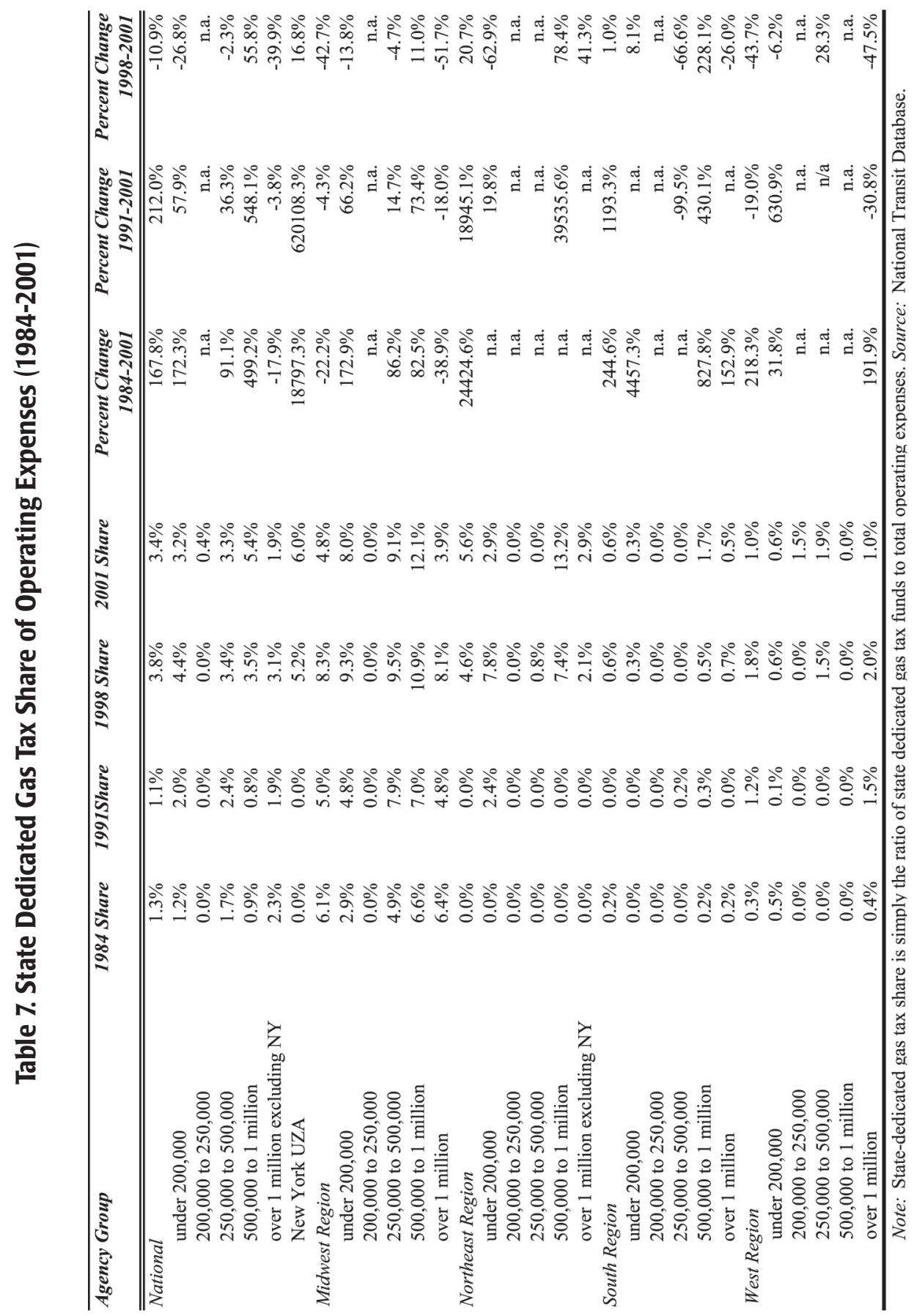


Journal of Public Transportation, Vol. 8, No. 3, 2005

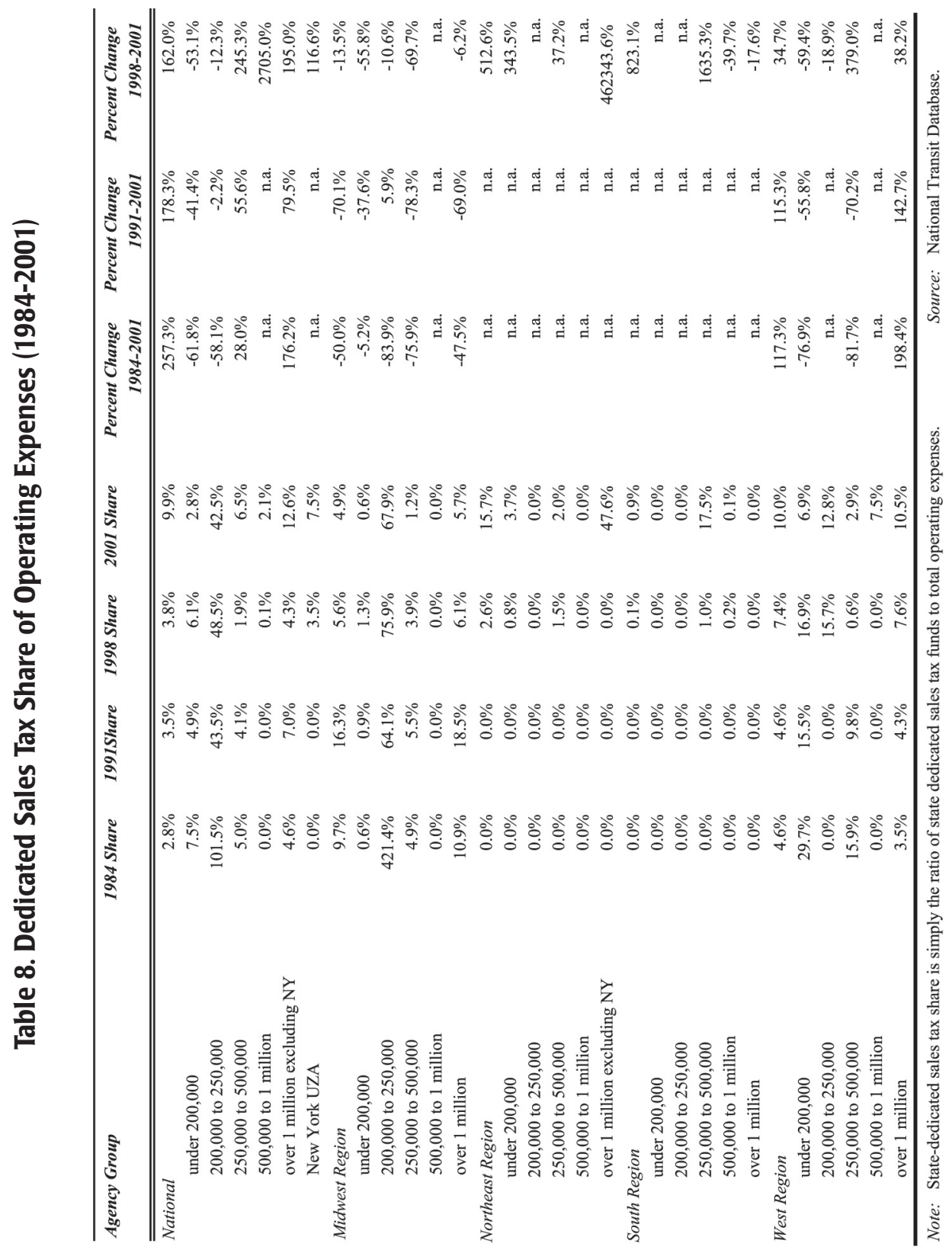


in the New York urbanized area, with most of the remainder among agencies in the largest West region urbanized areas (NTD 2002). Other than among agencies operating in these two environments, this finance instrument is relatively unimportant and its use has been flat or on the decline over the period examined in this article.

\section{Local Finance Mechanisms}

Local revenue sources are an increasingly important component of transportation finance, and of transit finance in particular. This is especially true for local option taxes ranging from dedicated sales taxes to fuel taxes to property taxes (Goldman and Wachs 2003). Such tax instruments have increasingly gained favor among elected officials and voters because of the speed and flexibility with which decisions can be made and because the tax proceeds often are used to provide highly visible local results (Goldman and Wachs 2003). This last point would appear to be more the case with capital investments, such as rail transit investments, than providing day-to-day operating support, yet the use of local revenues to support transit operations is quite widespread and has become significant in dollar terms as well. Local option taxes can enjoy widespread voter support-even among the vast majority of the local electorate who do not use transit; when a region faces a perceived traffic congestion crisis, the local political and business leadership is active in its support, the tax burden is relatively small and widely spread (e.g., incremental sales tax increases), the benefits (projects) are well-defined (e.g., specifically identified), and the benefits are geographically dispersed (Goldman and Wachs 2003; Haas et al. 2000; Werbel and Haas 2001). Dedicated sales tax measures that are devised to implement very specific transit projects-selected so as to reduce traffic congestion-have been especially popular and noticeably successful.

In 2001, local finance mechanisms contributed $\$ 5.4$ billion to the nation's transit expenditures, just over 46 percent of the amount expended on transit operations (NTD 2002). Local sources are most important in the South and West (65 percent and 58 percent, respectively) and less important in the Northeast (27 percent). The same patterns hold regardless of the size of urban area within which the transit agency operates (see Table 9). Nationally, the trend is toward decreased reliance on local revenue sources, although among certain groups of agencies, particularly in the Midwest and South, there is evidence of an increased reliance on local revenue sources. However, this picture is of a highly aggregated collection of instruments, and a slightly more complicated image may emerge when specific 
local revenue sources are considered. Local instruments suffer from similar shortcomings with respect to regressivity and equity as their state-levied counterparts, and, hence, these discussions will be omitted in this section.

Local General Revenue. One primary source of local financial support is through local general revenues. In 2001, local general revenue sources contributed more than $\$ 2$ billion toward the support of transit operations in the United States (NTD 2002). This number represented a 50 percent increase over 1984 levels. The general trend has been toward steady growth in the dollars raised in different parts of the country by this particular finance instrument, save in the Northeast where local general revenue dollars rose sharply in the mid-1990s and then declined slightly to their present level of $\$ 800$ million (NTD 2002).

Nationally, the trend is toward less reliance on local general revenue as a share of operating expenses (see Table 10). Since 1991, for example, the local general revenue share of operating expenses has fallen more than 40 percent among agencies nationwide. There are, however, regional variations in this trend. On a regional basis, reliance on local general revenue has fallen everywhere except in the Midwest, where it has increased more than 250 percent; however, it was a very small share in this region to begin with (2.8 percent). The Midwest continues to be the region least reliant on local general revenue. The Northeast is most reliant on local general revenue, largely due to the fact that states in this region have generally shied away from permitting the enactment of dedicated local taxes like sales taxes (Goldman and Wachs 2003). Local general funds tend to be the primary local revenue source for many agencies in the Northeast, which has a history of stronger state control over finances (Goldman and Wachs 2003). As a general rule, reliance on this instrument of finance is less among agencies in larger-sized urbanized areas than among those located in smaller ones.

Local-Dedicated Gas Tax. In recent years, there has been a proliferation of local option transportation taxes, ranging from local option gas taxes to property taxes to sales taxes (Goldman and Wachs 2003). The increased use of these dedicated local revenue sources for transportation in general, and transit in particular, has enabled local governments to fill in the financial gap left by state and federal governments and take more control over the selection of funded projects (Goldman and Wachs 2003). There is noticeable regional variation in the particular instruments that have been selected.

One instrument of local transit operating finance is the local gas tax, but it is not a widely employed instrument for transit operating support. Nationally, local gas 


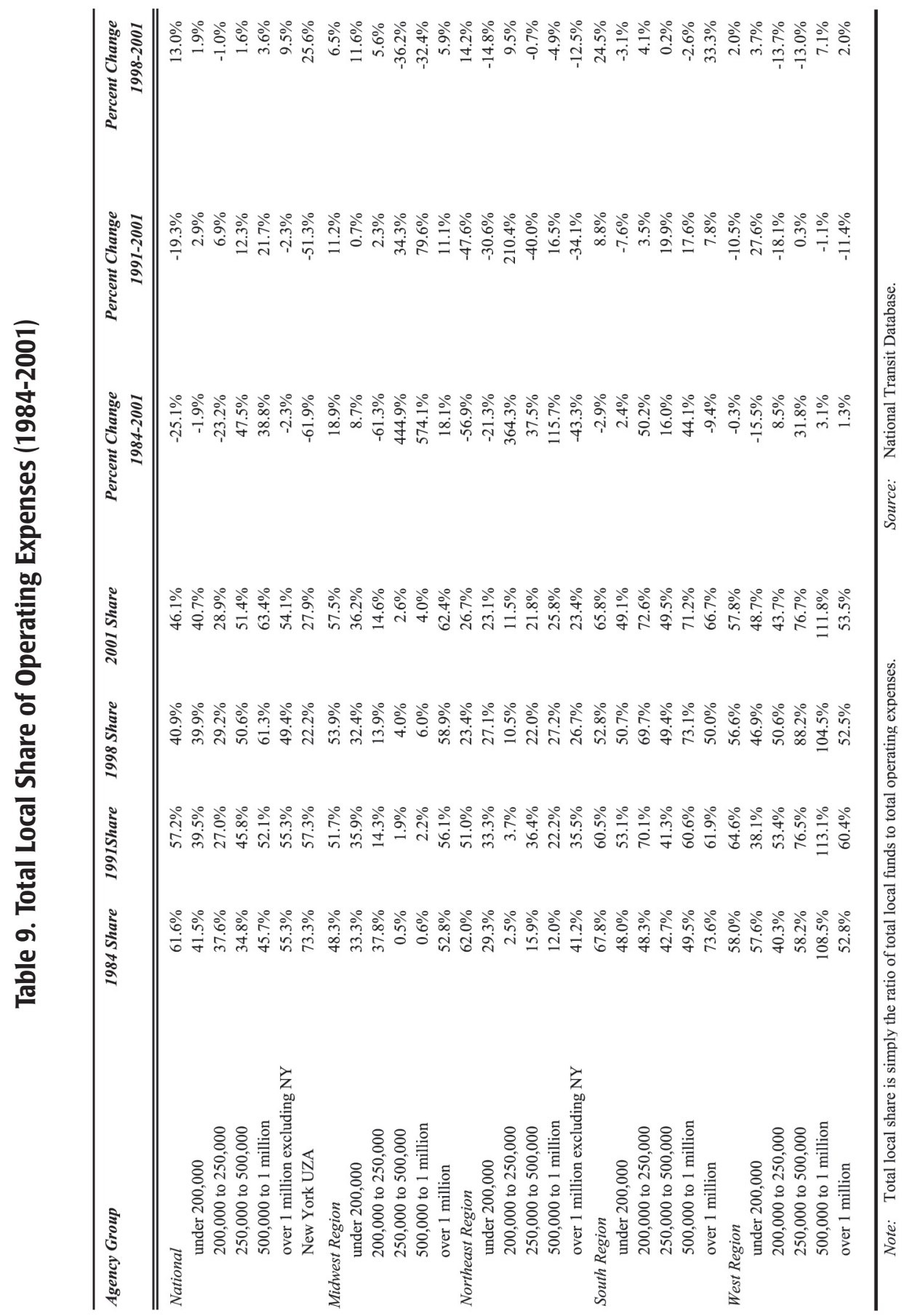




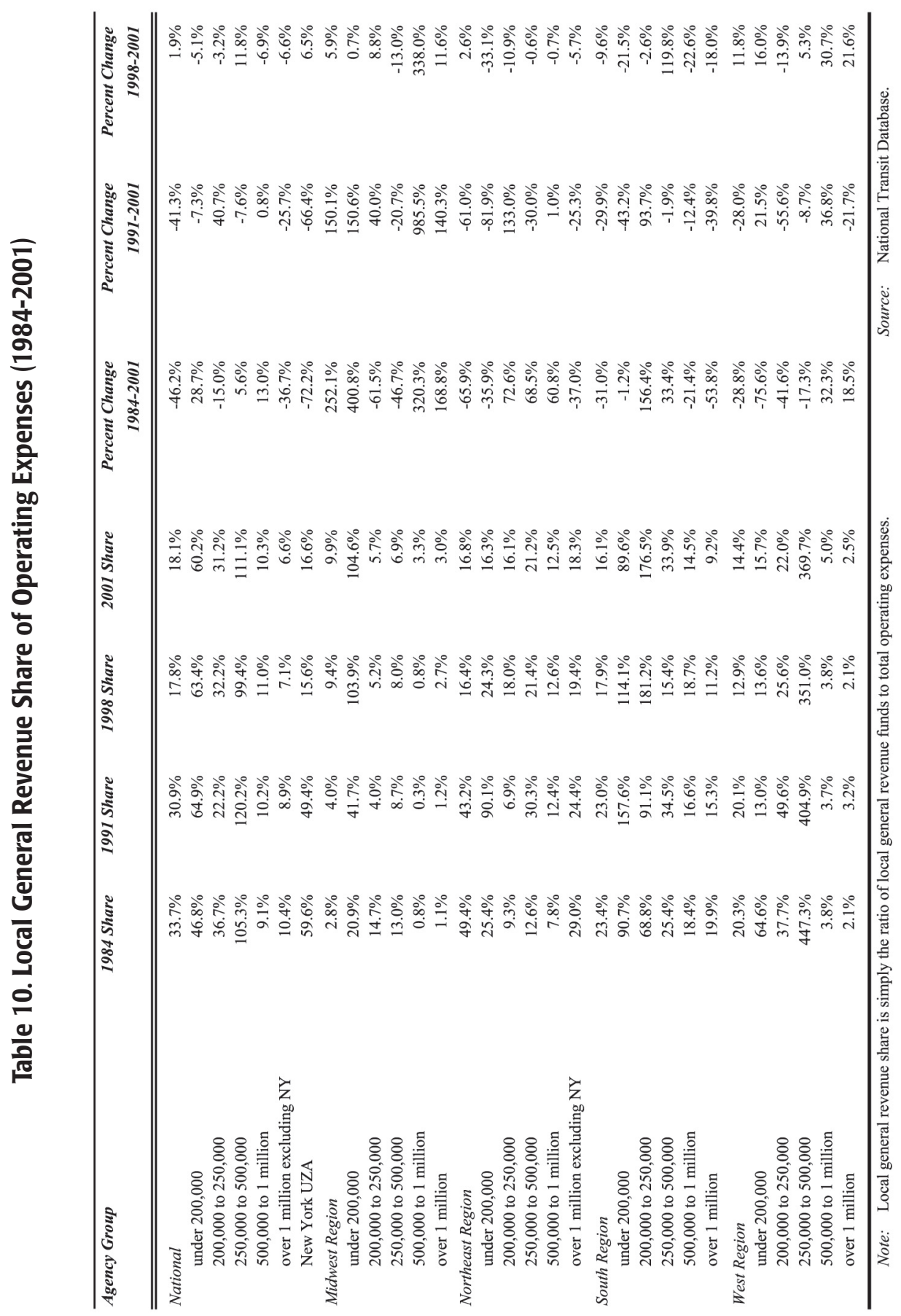


taxes raised $\$ 105$ million for transit operations in 2001 (NTD 2002). However, more than $\$ 90$ million was raised in the South region, and most of the remainder in a small number of urbanized areas in the West and Midwest. Local-dedicated gas tax revenues were less than 1 percent of transit operating expenses nationally, and reached a maximum of 4.4 percent among agencies in the South region (see Table 11). The South region is the one part of the country where use of this instrument is even modestly important and on the rise over the long term, although a few urbanized areas in the West have also embraced local gas tax finance of transit operations. Based on the trend examination presented here and the research on local option taxes conducted by Goldman and Wachs (2003), it is unlikely that this instrument will ever become an important part of the transit operating finance picture nationally.

Local-Dedicated Sales Tax. The most popular single local revenue source for transit operating support is the local-dedicated sales tax. In 2001, transit agencies received more than $\$ 2.3$ billion in local sales tax revenue for operating support, a more than fourfold increase since 1984 (NTD, various years). Local sales taxes are important sources of operating support in the West (nearly $\$ 1$ billion), South (just under $\$ 600$ million), and Midwest regions (\$476 million), but not in the Northeast ( $\$ 14$ million). In the Northeast region, most of this money is expended by agencies in the 500,000 to 1 million group of agencies; in other regions, agencies in most population groups receive a fairly even share of sales tax revenue. In most places where its use is important, local sales tax revenues used for transit operating support are growing.

Nationally, local sales tax revenues were just under 20 percent of total operating expenses in 2001 (see Table 12). This represents a 66 percent increase since 1984. Reliance on local sales taxes is more important in the West, which has a long history of using these instruments for transit finance, but the Midwest and South have nearly caught up. In the Northeast, on the other hand, its use remains limited to a small number of agencies in the 500,000 to 1 million population group. The evidence, presented here and elsewhere, suggests that local sales taxes will continue to be an important source of transit finance, but an extension of their geographic reach would require many states to loosen current restrictions on the use of local finance mechanisms.

Local-Dedicated Property Tax. Local property taxes are a modest source of transit operating revenue in the Midwest, South, and West regions and in the New York urbanized area. In 2001, local property taxes raised \$219 million for transit opera- 
tions nationwide (NTD 2002). This represented a more than 140 percent increase since 1984. Local property revenues grew by more than 300 percent in the Northeast and South and by a more modest 20 percent in the West and Midwest over the same time frame. In the West region, the use of local property taxes is more concentrated among agencies in the largest urbanized areas (over 1 million persons), while use is more evenly spread in the Midwest and South. In the Northeast, the New York urbanized area is the primary user of this finance mechanism.

In 2001, local property tax revenues were just under 2 percent of transit operating expenses nationally, but this number has declined slightly since 1984 (see Table 13). The importance of local property tax revenues is declining among most groups of operators, with the noticeable exception of those in the New York urbanized area and in the largest urbanized areas (over 1 million persons) of the Midwest, South, and West regions. This instrument is an important source of transit operating finance for agencies in smaller urbanized areas of the Midwest and South, where its importance has been relatively stable. Elsewhere, its use is quite modest and, if trends hold, will likely remain so.

Local-Dedicated Income Tax. The local-dedicated income tax is used primarily to support transit operations in a handful of the largest urbanized areas (over 1 million) of the Midwest, South, and West regions and in the New York urbanized area. In 2001, \$91 million was raised from this revenue source nationally, with $\$ 90$ million expended by agencies in the four groups noted above. The use of the local income tax is insignificant elsewhere. Nationally, it accounts for less than 1 percent of transit operating revenues, and among no group of agencies does it exceed 2 percent. It also has declined in importance everywhere save the West, where it is used in a small number of urbanized areas. The local income tax is unlikely to become an important revenue source for transit operations in the near future.

\section{Conclusions}

Recent policy changes, culminating in the passage of TEA-21, have served to reduce the federal government's role in supporting transit-operating expenses around the nation, and thus forced agencies to look elsewhere to support their expanding services. The data presented here show that agencies in different regions of the country have turned to different sources for aid. Agencies in the Northeast have turned to state revenue sources and, to a lesser extent, to local general revenue support. This is not surprising, given that many states in this region have barred subunits of 


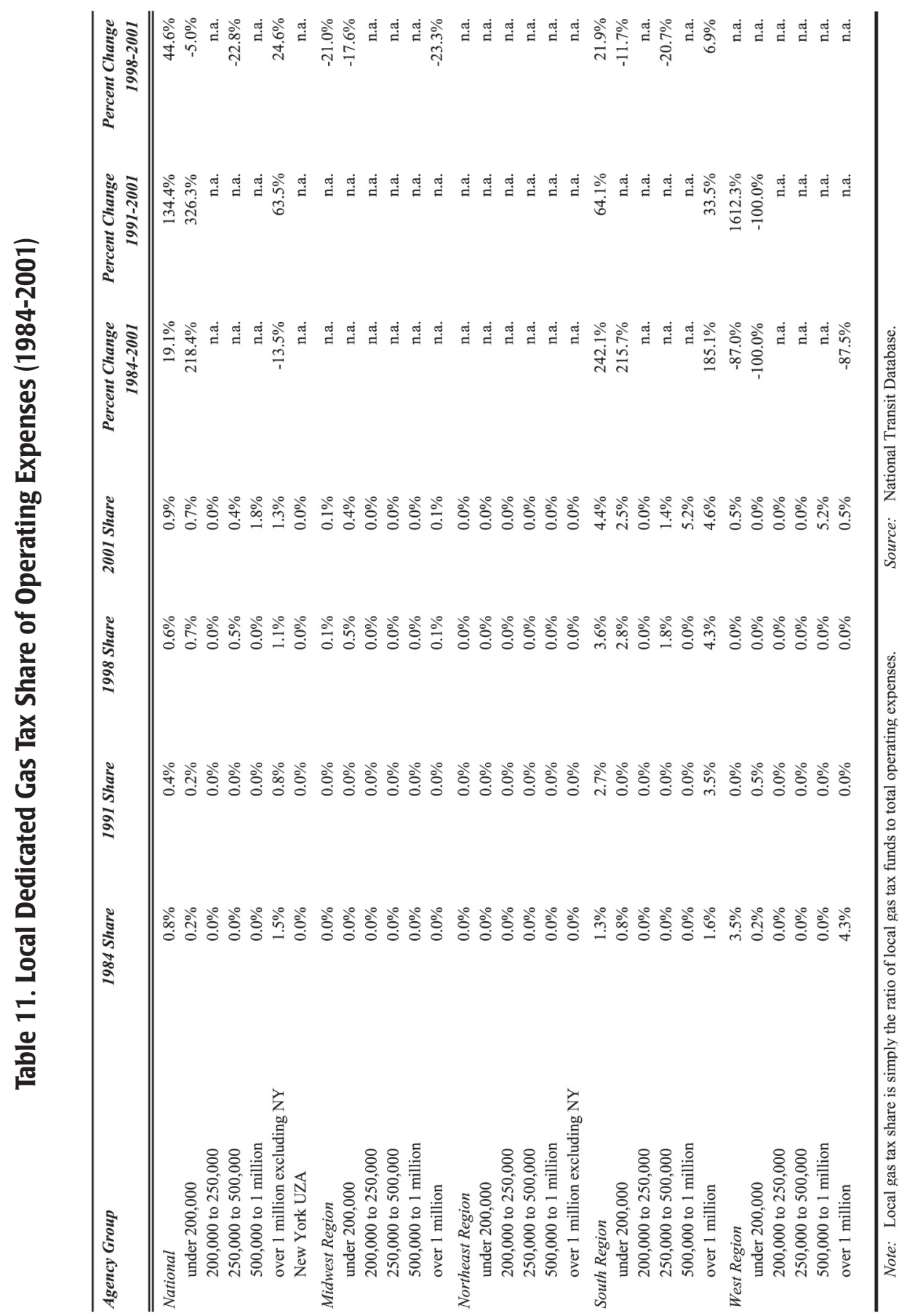




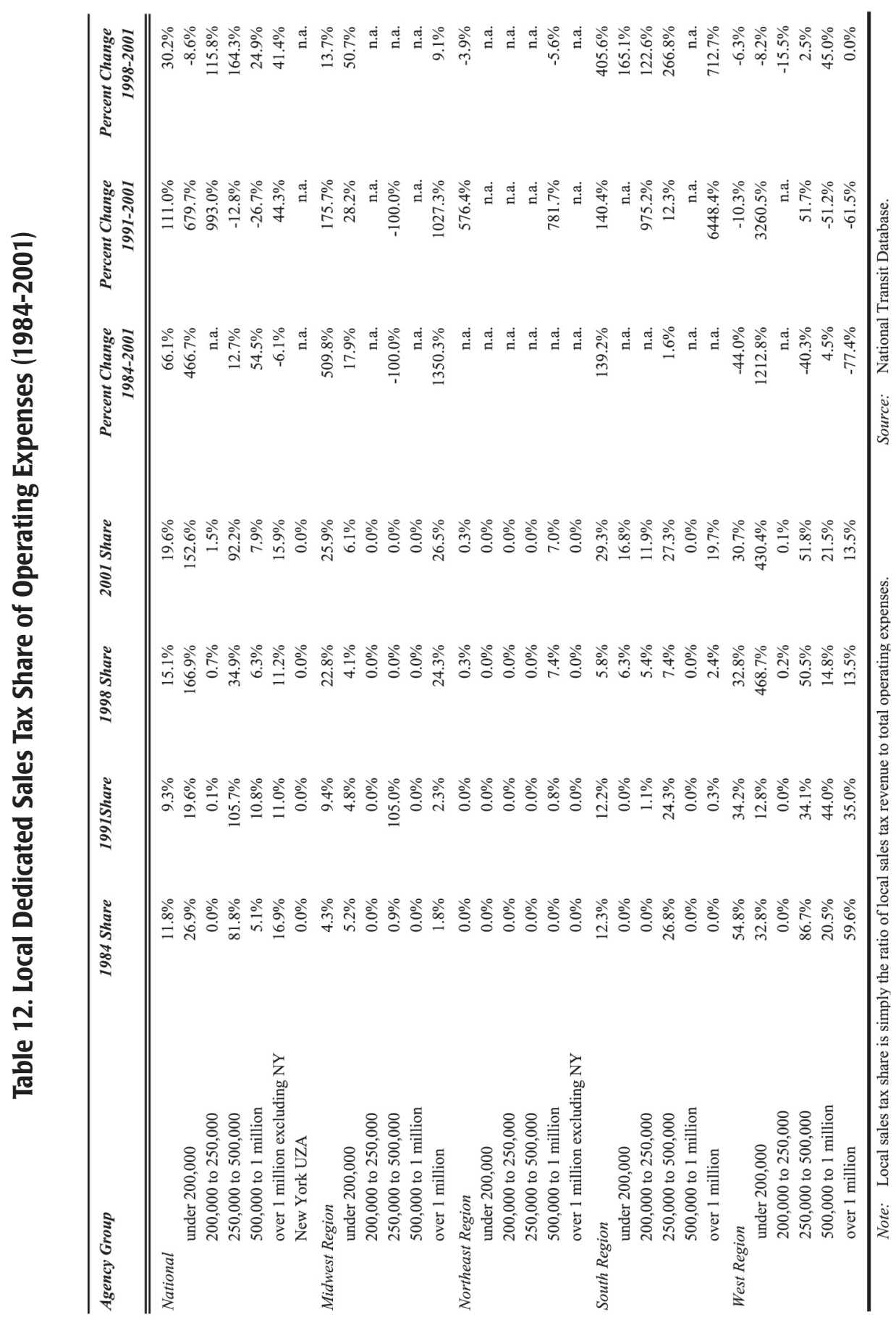




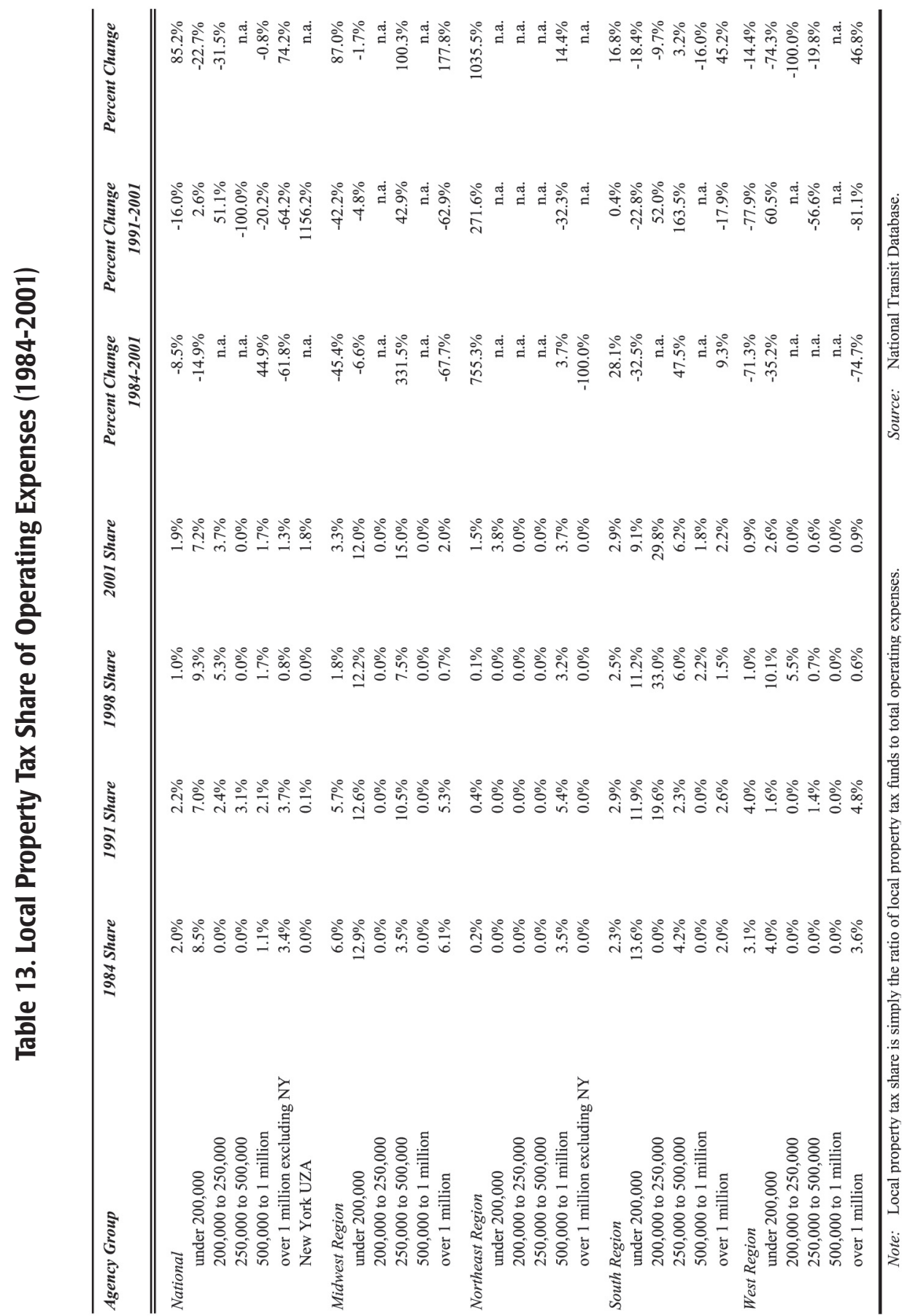


government from enacting many local revenue-generating mechanisms. Agencies in the Midwest, South, and West, on the other hand, have turned to a number of state and local sources, paying particular attention to the potential for local sales taxes to support transit operating expenses.

Agencies that need to raise new sources of revenue are likely to follow one or more of these strategies adopted by their peers. Currently, the most politically acceptable finance instruments are dedicated excise taxes (especially sales taxes) levied by local units of government. Such taxes have raised money for cash-strapped agencies, but are problematic in terms of their regressivity with respect to income and their disconnect from traditional user-pays philosophies of transportation finance. Transit agency administrators and local policy-makers will have to decide whether the benefits of transit service to lower-income individuals outweigh the regressivity of the instruments used to provide it. In most cases, they will undoubtedly answer in the affirmative.

\section{Acknowledgments}

The author would like to thank the anonymous referees for their many helpful comments and Myungjun Jang for his assistance with the data. The generous financial support of the Council on Research and Creativity at Florida State University also is acknowledged.

\section{Endnotes}

${ }^{1}$ Many critics of federal transit policy have argued that public subsidy is not efficient and does not enhance societal welfare. Winston and Shirley (1998) report that 75 percent of federal transit spending is consumed by higher labor and other service costs, while only 25 percent is used to maintain low fares or improve service for riders. Their estimates are based on a review of an extensive literature on the topic.

${ }^{2}$ The mid-1990s marked the first significant cuts in the dollar amounts supplied by the federal government to support transit operations. However, the relative federal contribution to transit operating support began to decline in the 1980s, as federal financial support failed to pace the increase in service provided by U.S. transit operators. 
${ }^{3}$ From time to time, the federal government has reclassified some operating and maintenance expenses to make them eligible under capital grants programs. TEA21 and ISTEA also increased flexibility in how agencies use their funds. These policy changes do not negate the research presented here.

${ }^{4}$ The data points presented in tables for this article are for 1984 (earliest year in the database), 1991 (ISTEA), 1998 (TEA-21), and 2001 (most recent year in the FTIS software when this research began). Data for all intervening years also were examined.

${ }^{5}$ This research originally was prompted by interest in the effect of the 1998 elimination of federal operating assistance to agencies in urbanized areas with more than 200,000 persons, and this interest led to the selection of the particular population categories employed here.

${ }^{6}$ For the national Under 200,000 group of agencies, the annual changes in federal operating subsidy dollars were statistically significant in every year from 1998 to the present. For the nation as a whole, the changes in the late 1990s, especially post-TEA-21, were statistically significant.

${ }^{7}$ This second approach, which considers a particular revenue source as a percent or share of total operating expenses, is used throughout the remainder of the article.

${ }^{8}$ The elasticities would be slightly less elastic for transit-dependent and peakperiod riders and slightly more elastic for choice riders and off-peak riders (Litman 2004a).

${ }^{9}$ Data from 1984 has been excluded from this discussion due to inconsistent entries in the National Transit Database for this year. 


\section{References}

APTA. 2004. American Public Transportation Association website section on reauthorization proposals. Available at www.apta.com.

Brown, Jeffrey. 2003. The numbers game: The politics of the Federal Surface Transportation Program. Unpublished dissertation. Department of Urban Planning, UCLA.

Congressional Record. 1997, 1998. Washington, DC: U.S. Government Printing Office.

Federal Register. 1998. Available at the GPO Access website. www.gpoaccess.gov.

Federal Transit Administration. 2005. Summary of grants/grants programs. Available at http://www.fta.dot.gov/grant_programs/overview/9913_ENG_HTML.htm.

Federal Transit Administration. 2002. 2001 National Transit Database (cited as NTD). Tables extracted using FTIS software. Available at www.ntdprogram.com.

Federal Transit Administration. 1985-2001. National Transit Database, tables for various years from 1984 to 2001. Tables extracted using FTIS software. Available at www.ntdprogram.com.

Goldman, Todd, and Martin Wachs. 2003. A quiet revolution in transportation finance: The rise of local option transportation taxes. Transportation Quarterly 57(1): 19-32.

Haas, Peter, Kristen Massey, Linda Valenty, and Richard Werbel. 2000. Why campaigns for local transportation funding initiatives succeed or fail: An analysis of four communities and national data. San Jose State University: Mineta Transportation Institute Report 00-01.

Hilton, George Woodman. 1974. Federal transit subsidies: The Urban Mass Transportation Assistance Program. Washington, DC: American Enterprise Institute for Public Policy Research.

Johnson, Nicholas, and Daniel Tenny. 2002. The rising regressivity of state taxes. Washington, DC: Center on Budget and Policy Priorities.

Jones, David W. 1985. Urban transit policy: An economic and political history. Englewood Cliffs, NJ: Prentice-Hall.

Litman, Todd. 2004a. Transit price elasticities and cross-elasticities. Journal of Public Transportation 7(2): 37-58. 
Litman, Todd. 2004b. Evaluating public transit benefits and costs: Best practices guide. Victoria, BC: Victoria Transportation Policy Institute.

McCollom, Brian E. and Richard H. Pratt, et al. 2004. Traveler response to transportation system changes. Chapter 12. Transit Pricing and Fares. TCRP Report 95. Washington, DC: Transportation Research Board.

Pechman, Joseph A. 1985. Who paid the taxes, 1966-85? Washington, DC: The Brookings Institution.

Price Waterhouse, Multisystems, Inc., and Mundle and Associates. 1998. Funding strategies for public transportation. Transit Cooperative Research Program Report 31. Two volumes. Washington, DC: Transportation Research Board.

Pucher, John. 2002. Renaissance of public transport in the United States? Transportation Quarterly 56 (1): 33-49.

U.S. Department of Transportation Annual Appropriations legislation, FY 19942000.

Taylor, Brian D. 1991. Unjust equity: An examination of California's Transportation Development Act. Transportation Research Record: Public Transit 1297: 85-92.

Werbel, Richard, and Peter Haas. 2001. Factors influencing voting results of local transportation funding initiatives with a substantial rail transit component: Case studies of ballot measures in eleven communities. Mineta Transportation Institute Report 01-17. San Jose State University.

Winston, Clifford, and Chad Shirley. 1998. Alternate route: Toward efficient urban transportation. Washington, DC: Brookings Institution Press. 


\section{About the Author}

JEFFREY BROWN (jbrown2@fsu.edu) is an assistant professor of urban and regional planning at Florida State University. His research examines public transit, transportation finance, and urban transportation history. 